\title{
Carbon sequestration potential of parkland agroforestry in the Sahel
}

\author{
Eike Luedeling • Henry Neufeldt
}

Received: 5 July 2011 / Accepted: 6 March 2012 / Published online: 28 March 2012

(C) Springer Science+Business Media B.V. 2012

\begin{abstract}
Establishing parkland agroforestry on currently treeless cropland in the West African Sahel may help mitigate climate change. To evaluate its potential, we used climatically suitable ranges for parklands for 19 climate scenarios, derived by ecological niche modeling, for estimating potential carbon stocks in parkland and treeless cropland. A biocarbon business model was used to evaluate profitability of hypothetical Terrestrial Carbon Projects (TCPs), across a range of farm sizes, farm numbers, carbon prices and benefit sharing mechanisms. Using climate analogues, we explored potential climate change trajectories for selected locations. If mature parklands covered their maximum range, carbon stocks in Sahelian productive land would be about 1,284 $\mathrm{Tg}$, compared to $725 \mathrm{Tg}$ in a treeless scenario. Due to slow increase rates of total system carbon by $0.4 \mathrm{Mg} \mathrm{C}^{-1} \mathrm{a}^{-1}$, most TCPs at carbon prices that seem realistic today were not feasible, or required the participation of large numbers of farmers. For small farms, few TCP scenarios were feasible, and low Net Present Values for farmers made it unlikely that carbon payments would motivate many to participate in TCPs, unless additional benefits were provided. Climate analogue locations indicated an uncertain climate trajectory for the Sahel, but most scenarios projected increasing aridity and reduced suitability for parklands. The potentially severe impacts of climate change on Sahelian ecosystems and the uncertain profitability of TCPs make the Sahel highly risky for carbon investments. Given the likelihood of degrading environmental conditions, the search for appropriate adaptation strategies should take precedence over promoting mitigation activities.
\end{abstract}

\section{Introduction}

Recent increases in atmospheric greenhouse gas concentrations appear to be altering the global climate, and future projected increases are expected to continue this trend (IPCC

Electronic supplementary material The online version of this article (doi:10.1007/s10584-012-0438-0) contains supplementary material, which is available to authorized users.

E. Luedeling $(\bowtie) \cdot H$. Neufeldt

World Agroforestry Centre (ICRAF), United Nations Avenue, Gigiri,

PO Box 30677-00100 Nairobi, Kenya

e-mail: e.luedeling@cgiar.org 
2007). An important strategy for slowing anthropogenic climate change is sequestration of carbon dioxide from the atmosphere (Paustian et al. 1998; Thomson et al. 2010) by raising the carbon stocks of landscapes (Dumanski et al. 1998; Smith et al. 2008).

Establishing agroforestry on land that currently has low tree cover has been identified as one of the most promising strategies to raise carbon stocks on currently productive land without compromising food and fiber production (Albrecht and Kandji 2003; Kuersten and Burschel 1993; Montagnini and Nair 2004). Agroforestry is the deliberate integration of trees or other woody perennials into field crop or livestock systems, in order to exploit synergies and complementarities between different structural elements of the system. Agroforestry has been shown in many instances to lead to more diverse, more productive and more sustainable agricultural production than less integrated approaches (e.g. Cannell et al. 1996; Nair 2007; Sinclair 1999; Van Noordwijk and Lusiana 1998).

Carbon stock increases resulting from conversion of treeless land to agroforestry have been estimated at $3 \mathrm{MgC} \mathrm{ha}^{-1} \mathrm{a}^{-1}$ in tropical regions (IPCC 2000). Conversion of agricultural land to agroforestry has also been reported to entail substantial co-benefits for farmers, such as enhanced soil fertility, resilience to weather extremes and additional sources of farm income (Ajayi et al. 2007; Garrity 2004; Sanchez 1995). Tree-based agricultural systems in many parts of the world have been shown to have higher carbon stocks than treeless farming systems (Luedeling et al. 2011; Nair et al. 2009a, b) and to provide more environmental services (Jose 2009; Paustian et al. 1998).

Global carbon markets have opened up the possibility of payments to farmers for their contribution to climate change mitigation (Jose 2009). Although to date few carbon finance projects have focused on agroforestry, the volume of the combined compliance and voluntary markets in the forestry sector reached $30.1 \mathrm{MtCO}_{2}$-eq with a value of over US\$133 million in 2010, and market trends promise further growth (Diaz et al. 2011). Since other environmental services are increasingly included in carbon projects, agroforestry is becoming an attractive option for Terrestrial Carbon Projects (TCPs). Wendland et al. (2010) present a method for identifying promising areas for carbon projects in Madagascar that may also attract payments for biodiversity preservation. Milder et al. (2010) also highlight the potential for farmers to receive payments for non-carbon ecosystem services, which could be combined with carbon payments in order to make additional activities economically attractive.

Agroforestry systems in humid tropical regions can store substantial amounts of carbon, but little attention has been paid to potential carbon stocks in drier areas. Only Smith et al. (2008) provide an estimate for agroforestry in warm dry areas (at $-0.73-1.39 \mathrm{Mg} \mathrm{C} \mathrm{ha}^{-1} \mathrm{a}^{-1}$, with a mean of $0.33 \mathrm{Mg} \mathrm{C} \mathrm{ha}^{-1} \mathrm{a}^{-1}$ ), but these numbers were produced by assuming that agroforestry sequestered the same amount of carbon as agriculture with tillage and residue management. They considered only soil carbon and did not take into account above and belowground carbon sequestered in the trees. These numbers are thus unlikely to reflect the true potential of dryland agroforestry systems.

Another knowledge gap concerns the potential for smallholder farmers in dry areas to receive payments for planting trees via carbon markets. While some agroforestry carbon projects have been started in more humid areas, the economic viability of TCPs focusing on Sahelian parklands has never been explored.

This paper focuses on the traditional parklands of the West African Sahel (Bayala et al. 2002; Kho et al. 2001). This agroforestry system mimics the natural savannah (van Noordwijk and Ong 1999) by preserving mature trees of a range of species, among which annual crops are planted. Kindt et al. (2008) identified 110 tree species in Sahelian parklands, including Adansonia digitata L., Faidherbia albida (Delile) A.Chev., Guiera senegalensis J.F.Gmel. 
and Vitellaria paradoxa C.F.Gaertn. Typical field crops are millet (Pennisetum glaucum (L.) R.Br.), sorghum (Sorghum bicolor (L.) Moench), maize (Zea mays L.), groundnut (Arachis hypogaea L.) and cowpea (Vigna unguiculata (L.) Walp.). Grazing cattle, goats and sheep are also common in these systems. TCPs aiming to sequester carbon by establishing parklands would require participating farmers to plant trees on their cropland, or to promote natural regrowth of trees. Where TCPs also aim to alleviate poverty, such activities should preferably be carried out by small subsistence farmers.

The objective of this study is to close these knowledge gaps. We present a regional-scale estimate of the potential of Sahelian parklands to sequester carbon, and a projection of likely climate change impacts on the Sahel's capacity to sustain parkland agroforests. In addition to this regional approach, we explore the economics of hypothetical TCPs, both from the project management and from the farmer perspective, and discuss the potential of such projects to alleviate poverty among smallholder farmers. Finally, we use climate analogue analysis to explore the potential of three important parkland regions in the Sahel to sustain this type of agroecosystem in a range of future climate scenarios.

\section{Materials and methods}

\subsection{Potential areas for parkland agroforestry}

The extent of agroforestry parklands in the Sahel has never been mapped, and little information is available on the climatic and environmental requirements of such systems. Due to the paucity of data, we used the maximum entropy (MaxEnt) ecological niche modeling approach (Phillips et al. 2006) to estimate potential parkland areas. This approach is commonly used to model the distribution of plant or animal species, based on known geographic positions where the species or ecosystem of interest occurs, and on environmental data layers that are used to characterize the habitat at these locations (e.g. Hernandez et al. 2006; Hijmans and Graham 2006; Pearson et al. 2007; Phillips and Dudík 2008). The MaxEnt method then assigns suitability scores to all grid cells within the study extent, based on environmental requirements of the species obtained from the input data. These scores express the potential of any point in the study area to sustain the species or ecosystem of interest. In this study, we applied the MaxEnt method to estimate suitable habitat for parkland agroforestry systems across the drier part of West Africa. We obtained a total of 101 reported occurrences of parklands from 18 published references (Bayala et al. 2006; Bayala et al. 2004; Bouvet et al. 2004; Deans and Munro 2004; Gijsbers et al. 1994; Kater et al. 1992; Kelly et al. 2004; Kho et al. 2001; Kindt et al. 2008; Maranz et al. 2004; Odebiyi et al. 2004; Reij et al. 2005, 2009; Takimoto 2007; Tilander et al. 1995; Timmer et al. 1996; Traore et al. 2004; Tschakert 2004). These 101 point locations were distributed throughout the Sahelian and Sudanian climate zones, while no sites from the moister Guinea savannah region were included. Even though the latter zone also has productive parklands, this zone was excluded to preserve the focus on dryland agroforestry systems. Environmental data layers were mean precipitation and mean daily temperature extremes for all months of the year, obtained from the WorldClim database (Hijmans et al. 2005). Based on the MaxEnt suitability scores (ranging from $0=$ unsuitable to $1=$ optimal), we interpreted all areas with scores of 0.2 or higher as suitable for parkland agroforestry. Since this threshold placed 99 out of 101 reported parkland occurrences in suitable areas (Fig. SF1 in the Supplementary Materials), it was accepted for determining suitability for parklands in areas where no information on the presence or absence of this ecosystem was available. We then confined 
the assessment to all areas classified as agriculturally productive land in 2000, according to a 2-km resolution dataset on land use in West Africa (Reij et al. 2009; US Geological Survey 2007). Besides climatic conditions, existence of parklands depends also on other factors, such as farmer decisions about preserving or removing parkland species on their farms. Nevertheless, there is likely a climatic zone, in which maintaining parklands is agronomically reasonable, and farmers will decide to preserve trees predominantly in this zone. We therefore used only climatic parameters for modeling suitability for parklands.

\subsection{Potential carbon stocks}

We found only three studies that have compared parkland systems with cultivated land (Tab. ST1 of the Supplementary Materials). Takimoto et al. (2008) investigated carbon stocks in five different land use systems in the Ségou region of Mali, including parklands and two recently established types of agroforestry (fodder bank and live fences). Since this study did not include a treeless baseline, we used the two recently established agroforestry systems as a substitute. This approach seemed acceptable, because above-ground C stocks in these systems were very low compared to parklands and also compared to soil carbon. Woomer et al. (2004) analyzed terrestrial carbon stocks in various environments of Senegal, including parkland and cultivated land in the Drier Sudanian Woodland of the Old Peanut Basin and the SudanoGuinean Transition zone. Tschakert (2004) focused on parkland systems in the Old Peanut Basin, providing carbon stock estimates for 21 sites, 18 of which could be classified as parkland or cultivated land. Estimates of combined carbon stocks in trees, shrubs and the upper $40 \mathrm{~cm}$ of the soil for each study were used for further considerations. For each study, all carbon stock estimates for parkland and for cultivated land were averaged, and these were then averaged over all three studies. The scarcity of available data did not allow differentiation by soil type or environmental conditions. Total carbon stocks in treeless cropland and parkland were then estimated by multiplying potential areas and carbon stocks per area.

\subsection{Annual carbon sequestration rates and TCP economics}

Converting potential carbon stocks into $\mathrm{C}$ sequestration rates requires knowledge of the time needed to reach the potential. Long-term observations of $\mathrm{C}$ stock increments over several decades are not available, but Tschakert (2004) used the CENTURY carbon flux model to estimate carbon dynamics of a Faidherbia albida plantation established on cultivated land in Senegal that was formerly covered by savannah vegetation. Carbon levels declined dramatically at the onset of cultivation and still had not fully recovered 50 years after establishment of the plantation. Takimoto et al. (2008) dated the establishment of parklands in Mali to at least 35 years ago. We adopted 50 years as a reasonable estimate of the time to reach maximum carbon stocks.

Besides the carbon sequestration rate, the economics of Terrestrial Carbon Projects (TCPs) depend on a range of other factors, such as the costs of project management, monitoring, reporting and verification of sequestered carbon (MRV). High costs can easily render a project infeasible even if carbon benefits are large on the landscape scale. We modeled TCP economics using a financial carbon accounting tool used by practitioners for planning TCPs (Tanja Havemann, pers. comm.). The tool was developed for a CARE Agriculture, Forestry and Other Land Use (AFOLU) project in western Kenya (CARE 2011), and adjusted to fit price structures in the Sahel (Antoine Kalinganire, pers. comm.; Table 1). To test whether TCPs could provide benefits for resource constrained farmers, we compared their performance across different land holding sizes, with average areas of new 
Table 1 Parameters used for the hypothetical Terrestrial Carbon Projects in the Sahelian parklands

\begin{tabular}{|c|c|c|}
\hline \multicolumn{2}{|l|}{ Parameter } & Values \\
\hline \multicolumn{2}{|c|}{ Farm size scenarios (parkland area) } & $2,4,6,8$ and 10 ha \\
\hline \multicolumn{2}{|c|}{ Discount rate } & $12 \%$ \\
\hline \multicolumn{2}{|c|}{ Trees planted per hectare } & 200 \\
\hline \multicolumn{2}{|c|}{ Sequestration rate per year } & $1.47 \mathrm{Mg} \mathrm{CO}_{2} \mathrm{ha}^{-1}$ \\
\hline MRV & $\begin{array}{l}\text { Mapping (once) } \\
\text { Monitoring (per year) } \\
\text { Verification (per } 5 \text { years) }\end{array}$ & $\begin{array}{l}\text { US } \$ 20,000+\mathrm{US} \$ 0.5 \text { per farm } \\
\mathrm{US} \$ 20,000+\mathrm{US} \$ 0.5 \text { per farm } \\
\mathrm{US} \$ 20,000+\mathrm{US} \$ 0.5 \text { per farm }\end{array}$ \\
\hline Staff & $\begin{array}{l}\text { Project manager } \\
\text { Extension workers }\end{array}$ & $\begin{array}{l}1 \\
1 \text { per } 2,000 \text { farms (rounded up to next integer) }\end{array}$ \\
\hline Staff cost & $\begin{array}{l}\text { Project manager } \\
\text { Extension workers } \\
\text { Training }\end{array}$ & $\begin{array}{l}\text { US } \$ 15,000 \text { per year }(+10 \% \text { overhead) } \\
\text { US } \$ 1,600 \text { per year }(+10 \% \text { overhead) } \\
\text { US } \$ 1,000 \text { per year }\end{array}$ \\
\hline \multicolumn{2}{|c|}{ Travel expenses } & US\$2 per farm \\
\hline Vehicles & $\begin{array}{l}\text { number of cars }{ }^{\text {a) }} \\
\text { number of motorcycles }\end{array}$ & $\begin{array}{l}1 \text { per } 50,000 \text { farms (rounded up to next integer) } \\
1 \text { per } 2,000 \text { farms (rounded up to next integer) }\end{array}$ \\
\hline
\end{tabular}

a) Purchase costs: US\$30,000; vehicle life: 5 years; re-sale value: US $\$ 5,000$; operating costs: US $\$ 6,500$ p.a.

b) Purchase costs: US $\$ 3,000$; vehicle life: 3 years; re-sale value: US $\$ 1,000$; operating costs: US $\$ 1,000$ p.a.

parklands of 2, 4, 6, 8 and 10 ha. Average farm size in the Sahel is around 5 ha in parkland regions of Senegal (Stéphenne and Lambin 2001) and Burkina Faso (Reij et al. 2009), so that this set of sizes should be representative of the range of farm sizes among small and medium-sized Sahelian farmers. Two-hectare farms likely represent the smallest, and likely poorest, landholders, whereas the high end of the farm size spectrum should describe the largest farms of a typical village community. The main outputs of the model are the amount of carbon dioxide sequestered in woody biomass or soil and the Net Present Value (NPV) of the operation, both for the project managers and for individual farmers. The NPV is the sum of all revenue over the 25-year life span of the project, with each year's revenue divided by $(1+d r)^{a}$. In the equation, $d r$ is the discount rate and $a$ the year after project inception, in which the revenue is accrued. We used a discount rate of $12 \%$, which is typical for decisions by businesses on long-term investments in developing countries.

We simulated two different benefit sharing mechanisms, resembling two farmer compensation structures currently existing in Kenya. Payment option 1 (P30 \%) assumes that farmers receive $30 \%$ of gross income from carbon sales every 5 years, which is typical of many projects approved by the Verified Carbon Standard (VCS 2011). Payment option 2 (P0.02) assumes a payment of $\$ 0.02$ annually for each existing tree, similar to the approach taken by the International Small Group and Tree Planting Program (TIST; www.tist.org). We ran the model for a number of combinations of farm size, payment option, carbon price and numbers of farms in the project to gain understanding about the framework that must exist for TCPs in the Sahel to be viable.

\subsection{Climate analogues and future suitability}

The climate analogue approach follows the premise that most projections of the climate at a given location correspond to climate that is currently observed somewhere else. Given 
sufficient similarity of other environmental factors, the ecosystems that exist at the analogue location at present can be used to visualize climate change impacts at the target location. We determined climate analogues based on baseline (1950-2000 from WorldClim; Hijmans et al. 2005) climate conditions and projected conditions for three global climate models (CSIRO, HADCM3 and CCCMA), two greenhouse gas emissions scenarios (A2a and B2a) and three points in time (2020s, 2050s and 2080s) (CCAFS Downscaled GCM Data Portal; http://www.ccafs-climate.org). Climate variables used were mean precipitation and mean daily temperature extremes for all months of the year. The search for climate analogues was confined to Africa, for which all climate data layers were resampled to a spatial resolution of one sixth of a degree.

Climate analogues were determined for three exemplary sites in the Sahel: the Old Peanut Basin in Senegal (represented by the data point $\left.14.8^{\circ} \mathrm{N} ;-16.7^{\circ} \mathrm{E}\right)$, Ségou, Mali $\left(13.4^{\circ} \mathrm{N} ;-6.3^{\circ} \mathrm{E}\right)$ and Zinder, Niger $\left(13.8^{\circ} \mathrm{N} ; 9.0^{\circ} \mathrm{E}\right)$. Table ST2 of the Supplementary Materials summarizes changes in mean annual precipitation and mean daily temperature extremes for all climate models for the three sites. For each of the three locations, we first obtained projected climate conditions for all 18 climate scenarios. For each scenario and each site, all 36 climate variables (monthly Tmin, Tmax and precipitation) were then compared with conditions in all grid cells of the baseline scenario, using a Euclidean distance approach:

$$
\text { Climatic distance }=\sqrt{\sum_{\text {par }} \sum_{m} w_{p a r, m} \cdot\left(\frac{P_{p a r, m}-F_{p a r}, m}{n o r m_{p a r}}\right)^{2}},
$$

in which par is the array of weather parameters, $m$ is the list of all months in the year, $w_{\text {par, } m}$ is a weighting factor (specific to weather parameter and month; set to 1 for temperature variables and 2 for precipitation), $P_{p a r, m}$ and $F_{p a r, m}$ are the values of the respective parameter for the present and future scenarios, and norm $_{\text {par }}$ is a normalization parameter, set to the interquartile range of the distribution of the respective monthly values in the entire Africa-wide population of grid cells. Since the climate analogue approach has not yet been widely used, there is no guidance on how to select optimal values for weighting different climate metrics. Weights were thus chosen based on our intuition, placing twice as much importance on precipitation as on the temperature parameters.

The climatic distance is a good measure for the similarity between projected climate at the target site and the current climate of any other location. The grid cell, for which the distance measure was minimized, was identified as the best currently existing climate analogue of the sample location for the respective climate scenario. The 50 closest analogue locations were also identified. All analysis steps were implemented in R programming language.

\subsection{Evaluation of climate analogues}

Monthly climate information of the baseline scenario was processed into a simple aridity index consisting of precipitation divided by potential evapotranspiration (PET). Expressing rainfall as a fraction of the amount of water that could potentially be evaporated by soils or transpired by plants allows for classification of environments into aridity zones. For this index, PET was estimated separately for each month of the year (represented by the 15 th day of the month) using the Hargreaves equation (Hargreaves et al. 1985; implemented in ArcGIS model builder). Temperature inputs for this equation were calculated from the WorldClim temperature layers, whereas extraterrestrial radiation was calculated according to Allen et al. (1988). For all climate analogues identified for the three sites and for the 50 
closest analogues, the aridity index was sampled allowing a comparison of current and projected future aridity at the site. Future suitability of the three sample locations for parklands was explored by extracting MaxEnt suitability scores for the same locations.

\subsection{Climate change impacts on potential carbon stocks}

While expansion of parklands can raise regional-scale carbon stocks, the impact of climate change may lower carbon stocks. Ecological niche modeling allows projection of the extent and location of ecological niches for future climate scenarios, provided that all data layers used for characterizing the niche are also available for future scenarios. We determined MaxEnt scores for all 18 future scenarios (from WorldClim; Hijmans et al. 2005), and summarized potential parkland areas for all scenarios. We then used the same conversion factors as outlined above for calculating potential carbon stocks in cultivated land for two scenarios: 1) no parkland and 2) parklands cover the maximum extent possible. Lacking reliable data on future land use, we assumed in this calculation that the area covered by cultivated land will remain unchanged.

\section{Results}

\subsection{Potential parkland area and carbon stocks}

Within the study extent, all but the transition zone towards the arid Sahara Desert and the more humid region of Guinea were classified as climatically suitable for parkland agroforestry (Fig. 1), indicated by MaxEnt suitability scores of 0.2 or higher. Of the 36.1 million ha classified as agricultural land in the land use dataset, $77.2 \%$ were classified as suitable for parkland agroforestry (Table 2).

Among the three studies analyzed, carbon stocks ranged from 12.7 to $59.3 \mathrm{Mg} \mathrm{C} \mathrm{ha}^{-1}$ for treeless croplands, and from 22.2 to $70.8 \mathrm{Mg} \mathrm{C}^{-1}$ for parkland (Tab. ST1). Since data scarcity did not allow including the environmental and management differences causing this variation, we only used average carbon stocks of $26 \mathrm{Mg} \mathrm{C} \mathrm{ha}^{-1}$ in treeless cropland and

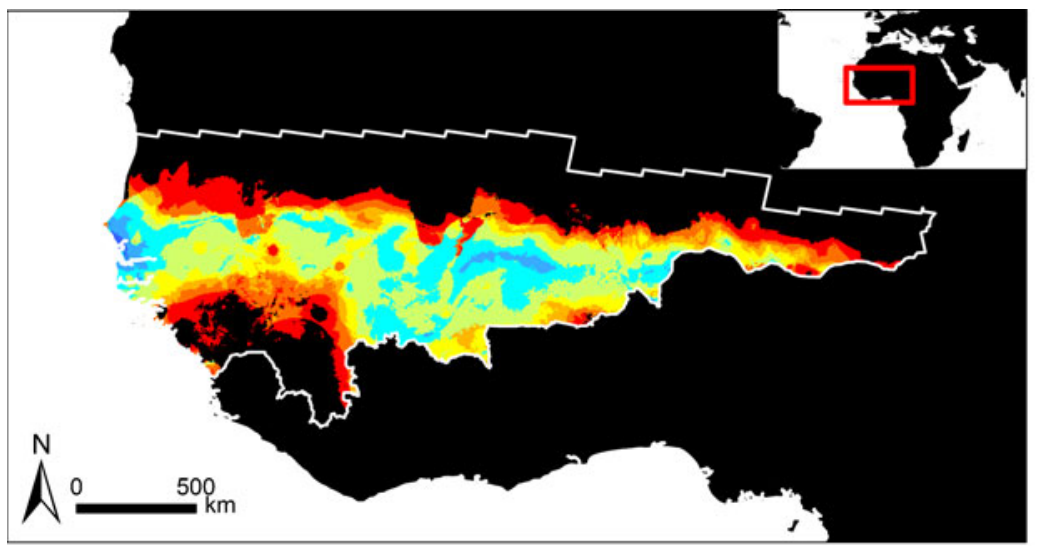

MaxEnt suitability score

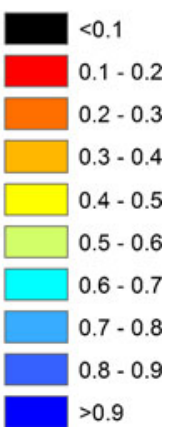

Fig. 1 MaxEnt suitability scores for parklands in West Africa, based on 101 published parkland locations and 36 monthly climate layers. High scores indicate suitability for parklands. The white line delineates the study extent 
Table 2 Suitability of Sahelian cropland (absolute and as share of total cropland) for parkland agroforestry, according to suitability classes based on MaxEnt scores

\begin{tabular}{llc}
\hline Suitability class & $\begin{array}{l}\text { Cultivated } \\
\text { area }\left(\mathrm{km}^{2}\right)\end{array}$ & $\begin{array}{l}\text { Share of cultivated } \\
\text { area }(\%)\end{array}$ \\
\hline Suitable for parkland $(\geq 0.2)$ & 279,020 & 77.2 \\
Unsuitable for parkland $(<0.2)$ & 82,265 & 22.8 \\
Total & 361,285 & 100.0 \\
\hline
\end{tabular}

$46 \mathrm{Mg} \mathrm{C} \mathrm{ha}^{-1}$ in parklands, indicating that parklands stored $20 \mathrm{Mg} \mathrm{C}^{-1}$ more than treeless cropland. Under the assumption that these estimates are representative of treeless agricultural land and parkland systems throughout the Sahel, potential carbon stocks can be estimated by multiplication of suitable or unsuitable areas and carbon stock per unit area. Such multiplication indicated total carbon stocks for the 'treeless agriculture' and 'maximum parkland' scenarios of 725 and 1,283 Tg C, respectively. Compared to treeless agriculture, the maximum parkland scenario would thus contain an additional $558 \mathrm{Tg} \mathrm{C}$, corresponding to $2.05 \mathrm{Pg}$ of sequestered $\mathrm{CO}_{2}$.

\subsection{Annual carbon sequestration rates and financial benefits}

Dividing the potential $\mathrm{C}$ sequestration $\left(20 \mathrm{Mg} \mathrm{C} \mathrm{ha}^{-1}\right)$ by the accumulation time (50 years) resulted in a mean sequestration rate of $0.4 \mathrm{Mg} \mathrm{C}^{-1} \mathrm{a}^{-1}$, corresponding to $1.47 \mathrm{Mg} \mathrm{ha}^{-1}$ $\mathrm{a}^{-1}$ of sequestered $\mathrm{CO}_{2}$. Assuming $\mathrm{C}$ sequestration at this constant rate in the simulation of TCP economics, a 100,000-farm project, with an average new parkland area of 10 ha per farm was able to sequester $28.8 \mathrm{Tg}$ of $\mathrm{CO}_{2}$ over 25 years (Fig. SF2 of the Supplementary Materials). If the same project targeted smallholders (2 ha of new parkland), only $5.8 \mathrm{Tg}$ of $\mathrm{CO}_{2}$ were sequestered.

The number of farms needed to make a TCP viable depended on the price of carbon, the parkland area per farm and the payment scheme. For all combinations of carbon payment scheme and farm size, projects were not viable for carbon prices below a defined threshold price (Fig. 2). For TCPs using the P0.02 payment scheme, threshold prices ranged from US $\$ 10.3$ per $\mathrm{Mg} \mathrm{CO}_{2}$-eq for 10 -ha farms to US\$15.5 per $\mathrm{Mg} \mathrm{CO}_{2}$-eq for a project focusing on 2-ha farms. In the P30 \% scenario, threshold prices were between US\$2.7 and US\$ 10.5 per $\mathrm{Mg} \mathrm{CO}$-eq (Fig. 2).

The Net Present Value of the TCPs depended on the number of farms enrolled, their sizes, the price of carbon and the payment scheme (Fig. 3). When using the P30\% scheme and targeting farmers with 6 or more ha of new parkland, NPV was positive, even at a low carbon price of US\$5 per $\mathrm{Mg} \mathrm{CO}$-eq, and profit margins were high at carbon prices $>$ US $\$ 10$ per $\mathrm{Mg} \mathrm{CO}_{2}$-eq and for projects including at least 50,000 mid-sized farms (4 ha or more). Projects focusing on smallholders ( 2 ha of new parklands) were only successful at high carbon prices, and generated much smaller NPVs than projects targeting larger farms.

TCPs using the P0.02 payment scheme, selling carbon at US\$20 per $\mathrm{Mg} \mathrm{CO}_{2}$-eq and targeting 10,000 or more farmers generated sizeable profits. However, at half the carbon price, closer to current values, project NPVs were negative for all scenarios (Fig. 3). At carbon prices exceeding US $\$ 30$ per $\mathrm{Mg} \mathrm{CO}_{2}$-eq, the P0.02 payment scheme consistently generated higher NPVs than the P30 \% scheme.

Farmer NPV depended entirely on farm size, if the TCP applied payment scheme P0.02 (Fig. 4). For smallholder farmers with 2 ha of new parkland, NPV was US\$70.75, compared with US\$353.74 for large holdings (10 ha). If payment scheme P30 \% was used, NPV depended also on the price of carbon, and exceeded those in the P0.02 scheme at carbon 


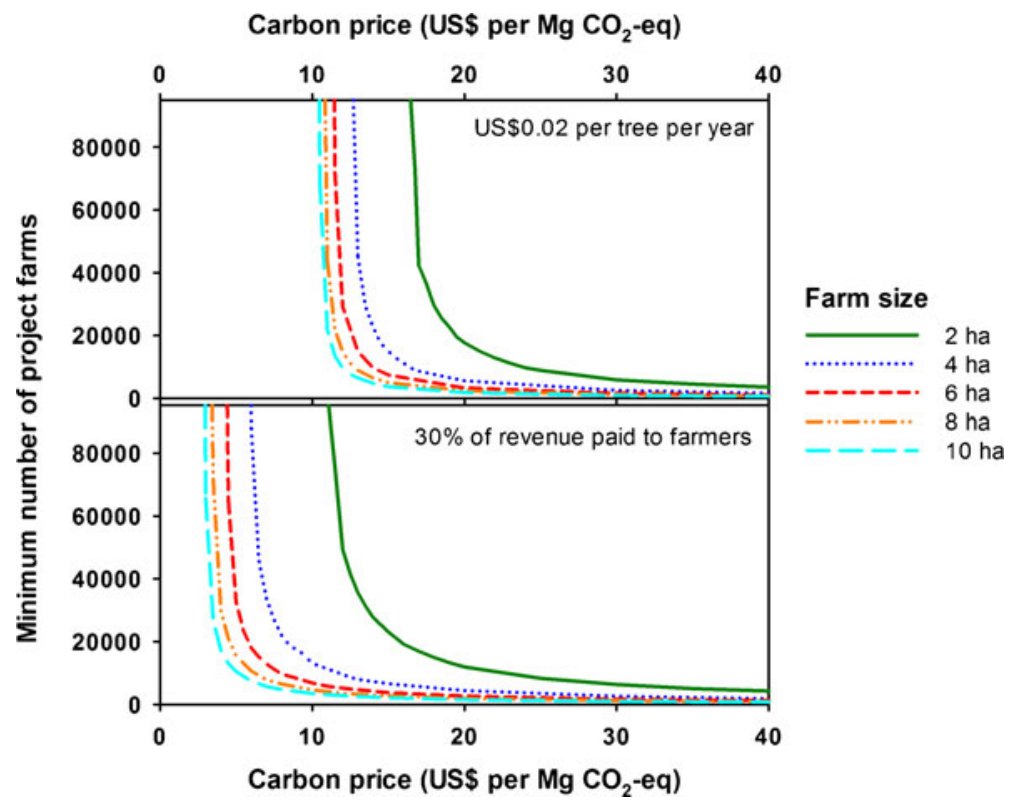

Fig. 2 Profitability thresholds for hypothetical TCPs in the Sahel, depending on the mean farm size, the number of farms, the carbon price and the payment scheme. For each farm size/payment scheme scenario, combinations of carbon price and number of farmers to the left of the lines signify that the project would incur a loss, whereas those to the right of the lines indicate profitable projects

prices above US\$39.14 per $\mathrm{Mg} \mathrm{CO}_{2}$-eq (Fig. 4). It should be noted that all these calculations are based on a number of assumptions about the cost structure of TCPs in the Sahel (Table 1). Nevertheless, we believe that our results are indicative of the reality of carbon projects targeting Sahelian smallholders.

\subsection{Climate analogues}

All climate analogues of the Old Peanut Basin in Senegal were located close to the area's current location (Fig. 5, top). For the B2a emissions scenario, aridity and climatic suitability for parkland were similar to present conditions for most climate scenarios, with one scenario (HADCM3; 2080s) projecting strongly increasing aridity (Fig. 6, top left). For the A2a emissions scenario, increasing aridity was evident for two of the climate models (CCCMA and HADCM3). MaxEnt suitability scores were in line with aridity projections, with mostly stable conditions for the B2a scenario, and declining suitability for most projections under the A2a emissions scenario (Fig. 6, bottom left).

For Ségou and Zinder, analogue locations were spread over a longitudinal range of several thousand $\mathrm{km}$, but with a small north-south extent (Fig. 5, middle and bottom), reflecting the latitudinal rainfall isohyets of the Sahel. For Ségou, the CCCMA model consistently projected decreasing aridity, while the other two models projected drier conditions (Fig. 6, top middle). Suitability of this location for parklands tended to decrease for all scenarios after the 2020s (Fig. 6, bottom middle). For nine out of 18 future scenarios, MaxEnt scores close to or below 0.2 for many of the 50 closest climate analogues suggest that conditions may deteriorate substantially in the future. 


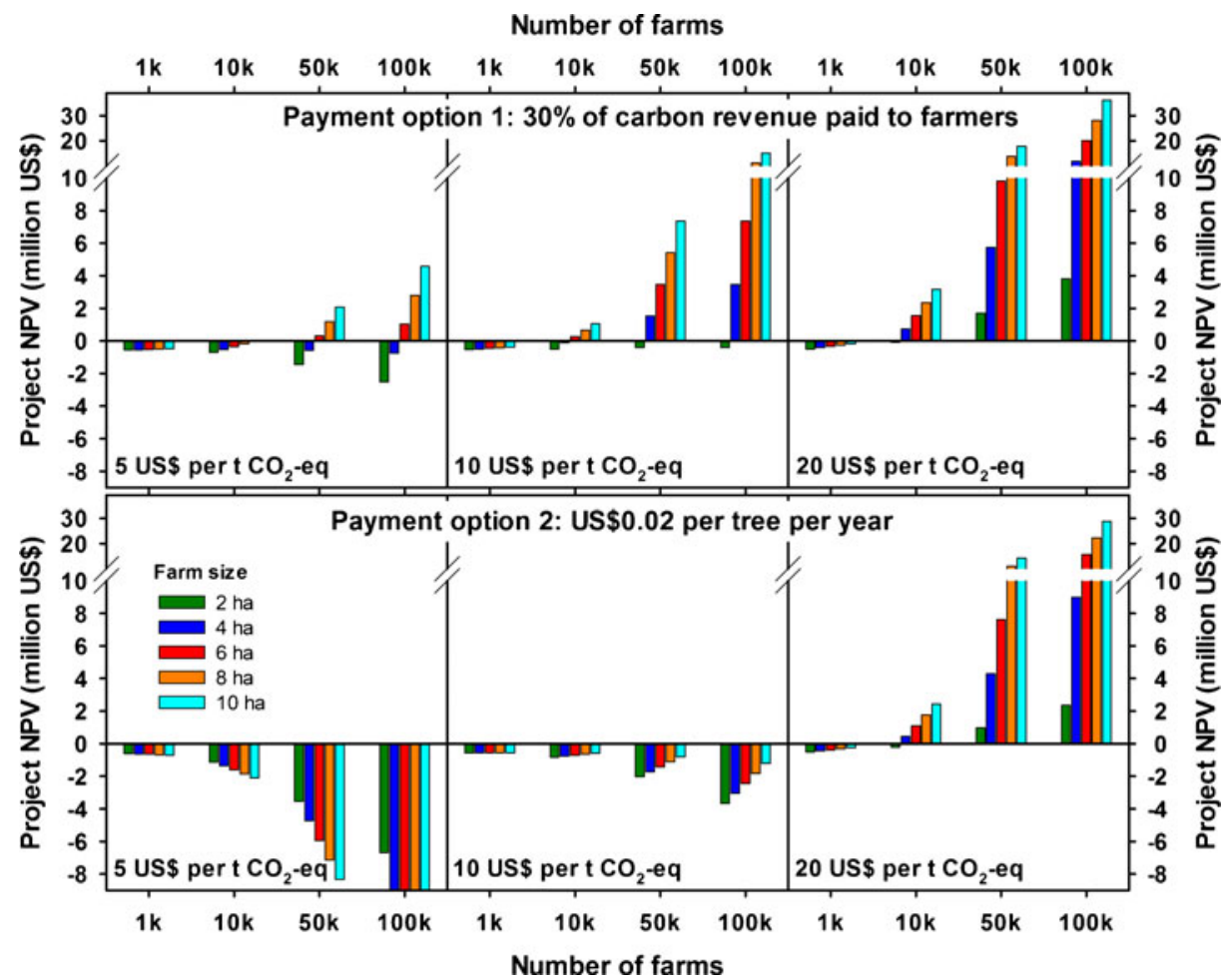

Fig. 3 Net Present Value (NPV) estimates of hypothetical Terrestrial Carbon Projects in the Sahel, depending on number of farms in the project, average farm size and payment scheme

For Zinder, projected rainfall changes were relatively small (Tab. ST2), but these had strong effects on aridity and MaxEnt suitability. For the 50 closest pixels to Zinder in the baseline scenario, aridity index values were low for all climate analogues (Fig. 6, top right). Suitability for parkland agroforestry was relatively low in the baseline, and fell below 0.2 in most future scenarios (Fig. 6, bottom right). Only in some analogue locations for 2020s

Fig. 4 Net Present Value (NPV) for farmers engaging in hypothetical Terrestrial Carbon Projects in the Sahel, depending on farm size, payment scheme and carbon price

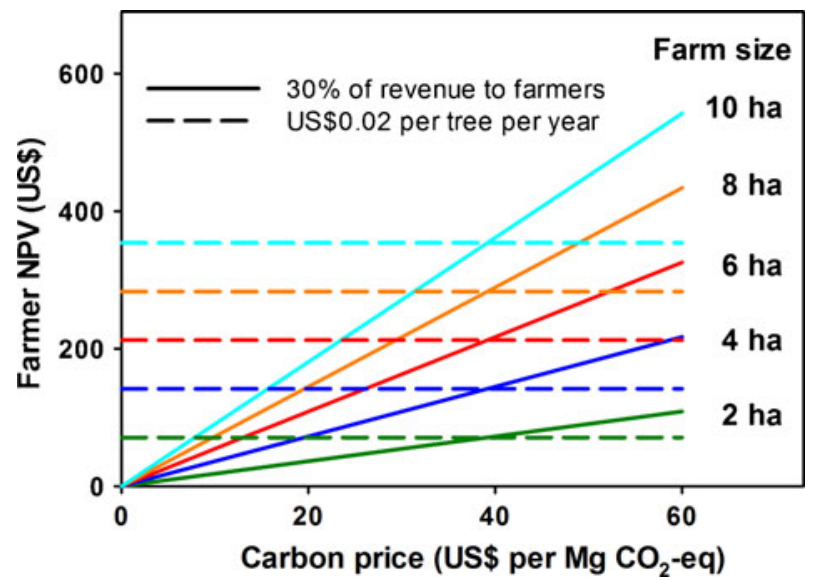



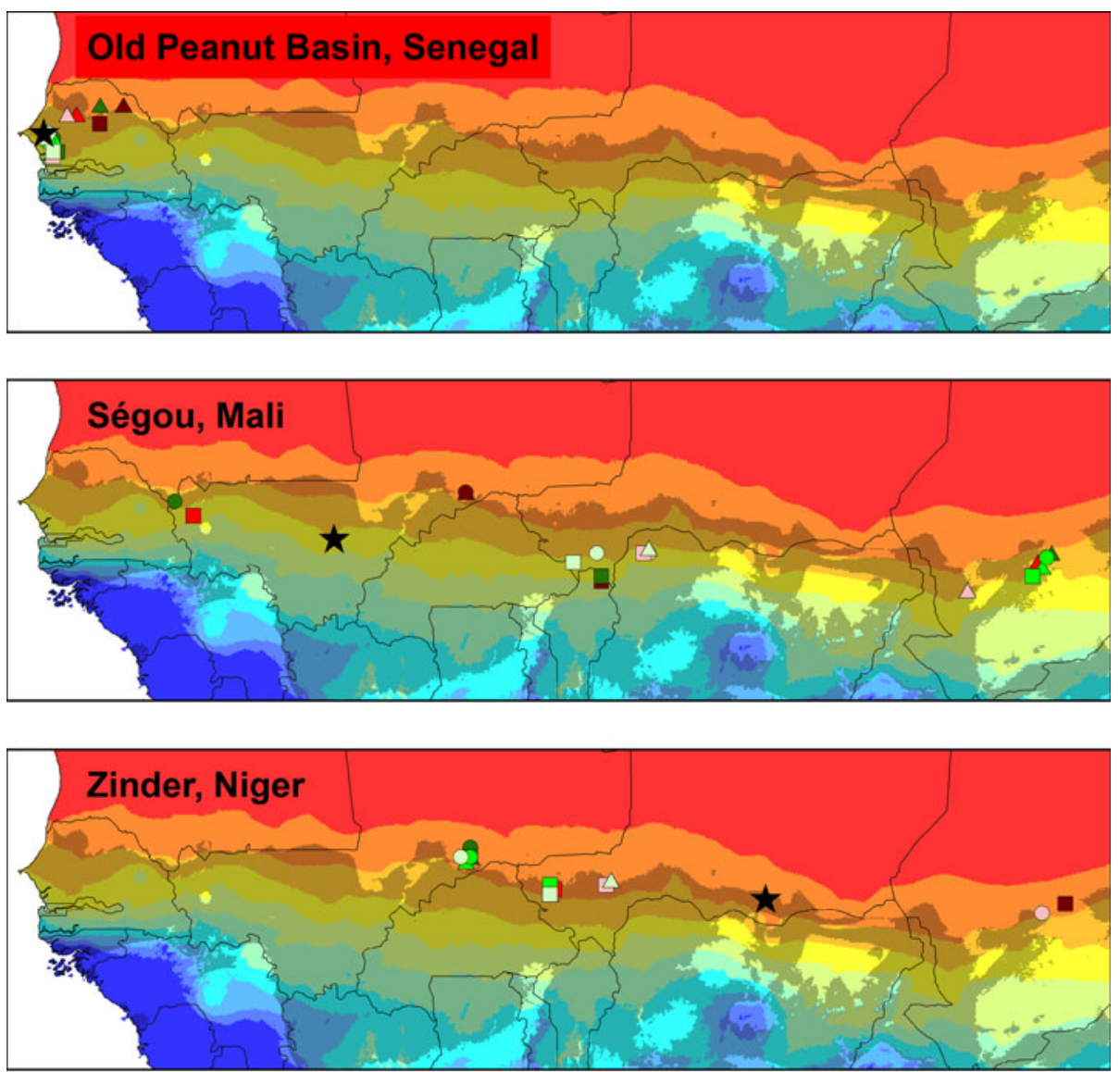

\section{Precipitation / PET}

\begin{tabular}{|c|c|c|c|}
\hline$<10 \%$ & $50-60 \%$ & $\square$ & СССМА \\
\hline $10-20 \%$ & $60-70 \%$ & 0 & CSIRO \\
\hline $20-30 \%$ & $70-80 \%$ & $\triangle$ & HADCM3 \\
\hline $30-40 \%$ & $80-90 \%$ & $\star$ & Current location \\
\hline $40-50 \%$ & $>90 \%$ & & \\
\hline
\end{tabular}

Emissions scenario B2a A2a

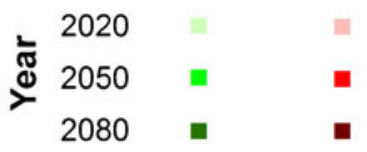

Fig. 5 Climate analogue locations for the Old Peanut Basin (Senegal, top), Ségou (Mali, middle) and Zinder (Niger, bottom) for 18 future climate projections. Climate analogues are the most similar locations in terms of current climate to climates projected for the target location in the future

scenarios did Zinder have suitability scores clearly above 0.2 . With the exception of the CCCMA 2050s scenario, all analogue locations representing the 2050s or 2080s were unsuitable for parklands.

For all three locations, aridity index and MaxEnt scores depended strongly on the climate model used. This difference probably stems from differences between models in anticipating future changes to the annual shifts of the Intertropical Convergence Zone (Bellucci et al. 2010), which are crucial determinants of seasonal rainfall in the Sahel. 
Aridity Index (Precipitation / PET)
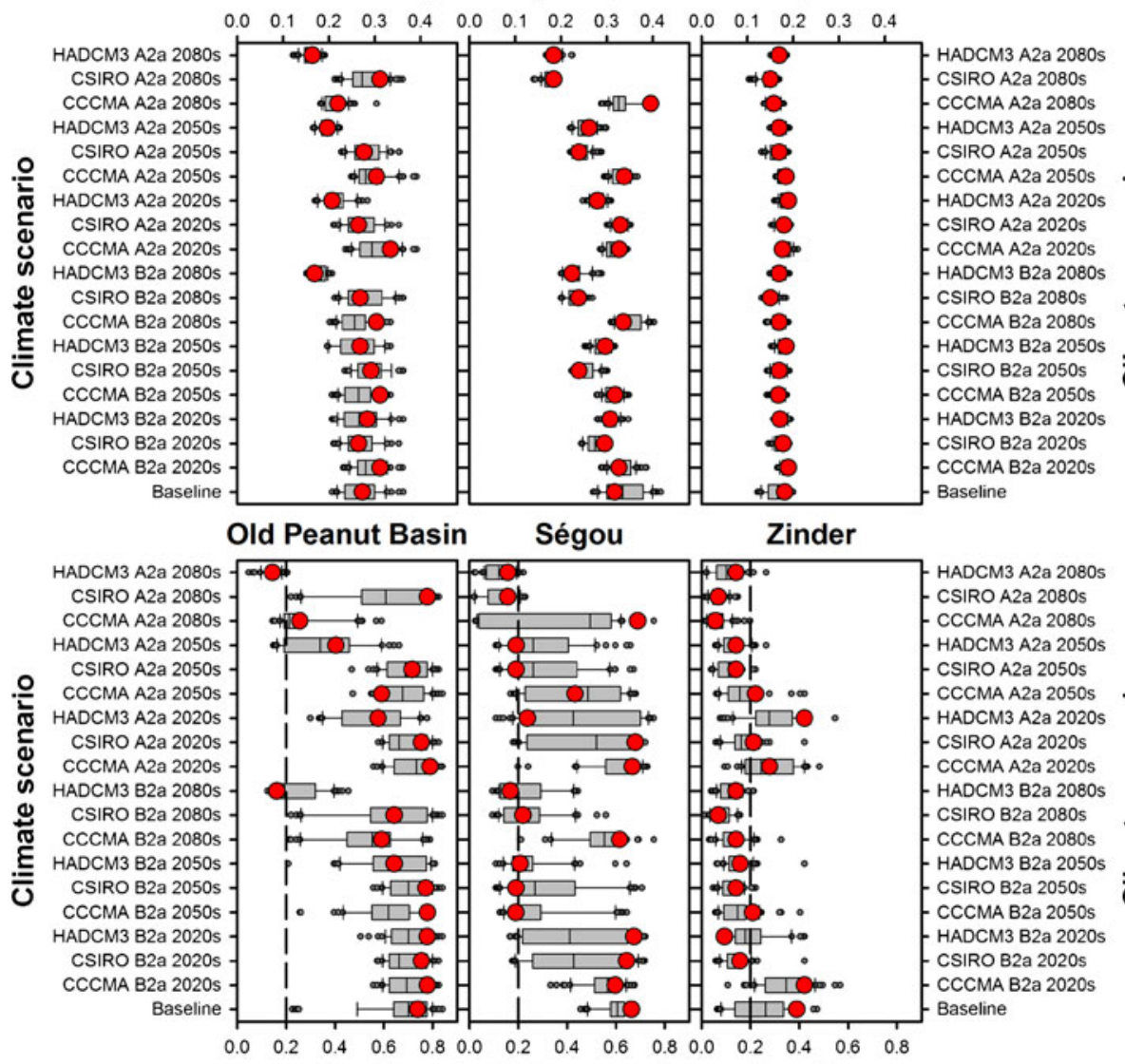

MaxEnt suitability score for parklands

Fig. 6 Aridity Index values (top) and MaxEnt suitability scores for parkland agroforestry (bottom) for the current locations of the Old Peanut Basin, Ségou and Zinder (baseline), as well as for the best available modern day climate analogues of projected future conditions at the sites for 18 future climate projections. The red dots indicate conditions at the best analogue location, while the box plots show the distribution of index values among the 50 closest analogue sites

\subsection{Future parkland areas and carbon stocks}

Projected climatic changes substantially affected MaxEnt suitability scores, with the area classified as unsuitable (scores $<0.2$ ) increasing dramatically in some projections (Fig. 7). Suitable areas were projected to contract. The B2a emissions scenario projected a larger suitable area for parklands than the A2a scenario, corresponding to weaker greenhouse gas forcing in the B2a scenario (Table 3). For all future scenarios, potential carbon stocks in parklands were lower than in the baseline, ranging between 977 and $1,308 \mathrm{Tg} \mathrm{C}$ by the 2080s (Fig. SF3 of the Supplementary Materials). While these results should be considered with caution due to the range of underlying assumptions, they do indicate substantial uncertainty in the amount of carbon that can be stored in Sahelian parklands in a future affected by climate change. 


\section{Agricultural areas suitable for parkland agroforestry}

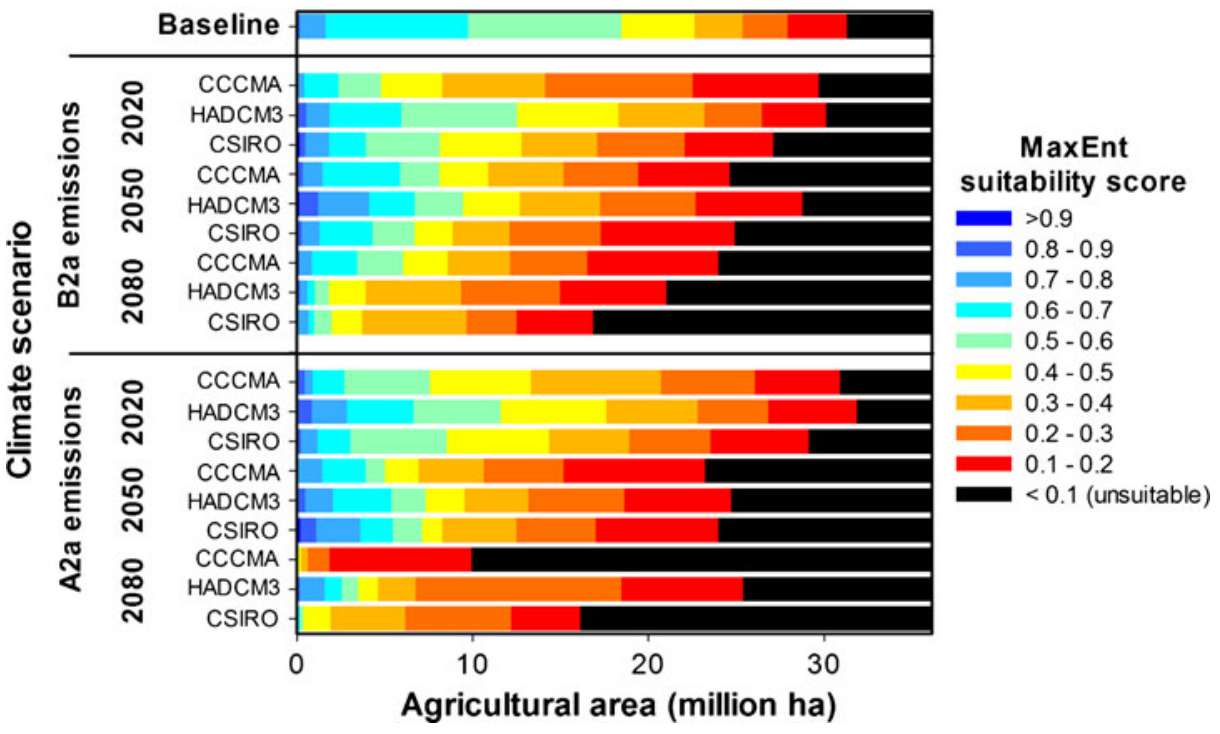

Fig. 7 Distributions of MaxEnt suitability scores across all Sahelian cropland for the baseline and 18 future climate scenarios

\section{Discussion}

\subsection{Viability of terrestrial carbon projects}

For the range of hypothetical TCP scenarios tested, only those with high carbon prices and/ or the inclusion of large numbers of farmers were financially viable. These estimates rely on optimistic assumptions about rollout time, adherence to project requirements and tree survival rate. However, TCPs may increase profitability by reducing project costs, as evidenced by the success of TIST projects in East Africa (with P0.02 payment).

Given these assumptions, our results indicate that carbon projects would run at the margin of profitability, or even be unprofitable, at current carbon price levels. Recruiting the large number of farmers required for a TCP to be profitable may pose logistic difficulties. The geographical areas covered by a TCP would be large, because many farmers would be

Table 3 Agricultural areas in the Sahel classified as unsuitable, suitable and highly suitable for parkland agroforestry, according to MaxEnt ecological niche modeling. Results are shown for the Baseline and for each combination of emissions scenario and time period. For future projections, averages and standard deviation of three Global Climate Models are shown

\begin{tabular}{llccc}
\hline $\begin{array}{l}\text { Time } \\
\text { period }\end{array}$ & $\begin{array}{l}\text { Emissions } \\
\text { scenario }\end{array}$ & Unsuitable $(<0.2)$ & $\begin{array}{l}\text { Suitable } \\
(0.2-0.5) \\
\text { Million ha }\end{array}$ & $\begin{array}{l}\text { Highly suitable } \\
(>0.9)\end{array}$ \\
\hline $2020 \mathrm{~s}$ & B2a & $12.5 \pm 2.4$ & $15.2 \pm 2.2$ & $8.5 \pm 3.9$ \\
& A2a & $10.7 \pm 1.7$ & $16.2 \pm 1.9$ & $9.2 \pm 2.1$ \\
$2050 \mathrm{~s}$ & B2a & $16.3 \pm 2.7$ & $11.7 \pm 1.4$ & $8.1 \pm 1.4$ \\
& A2a & $19.2 \pm 1.7$ & $10.5 \pm 0.8$ & $6.5 \pm 1.3$ \\
$2080 \mathrm{~s}$ & B2a & $21.5 \pm 2.0$ & $11.4 \pm 1.5$ & $3.3 \pm 2.4$ \\
& A2a & $25.3 \pm 8.4$ & $9.5 \pm 6.9$ & $1.3 \pm 1.9$ \\
Baseline & - & 8.2 & 9.4 & 18.5 \\
\hline
\end{tabular}


ineligible for a TCP or other Payment for Environmental Services scheme (Swallow et al. 2009; Wunder 2008) due to unclear or insecure tenure (Tschakert 2004; Woomer et al. 2004). Projects covering thousands of farmers across cultural groups and administrative boundaries would be difficult to manage. Managing a TCP of the required size would also imply high risks for the project developer. The high number of necessary participants, the long lag times between investment and break-even and the possibility that farmers can sell the trees they have planted within the project, among others, provide considerable risk that needs to be factored into the buffer and the insurance against default, both of which would raise project costs.

Probably the most limiting factor to the success of TCPs is their limited economic attractiveness for farmers. According to Tschakert (2004), annual farm household incomes in the Peanut Basin of Senegal ranged from $\$ 577$ to $\$ 2,293$ in 2001, and current per capita incomes are $\$ 755, \$ 1,252$ and $\$ 1,819$ for Niger, Mali and Senegal (World Economic Outlook database; http://www.imf.org). At a carbon price of US\$20 per $\mathrm{Mg} \mathrm{CO}_{2}$-eq, even for large farms and assuming the most beneficial payment scheme, farmer NPV would only be around US $\$ 350$. This means that the perceived revenue from a commitment over 25 years is substantially lower than the annual income of even the poorest group of farmers. For small (2-ha) farmers, with NPVs between US\$36 and US\$71 at US\$20 per $\mathrm{Mg} \mathrm{CO}_{2}$-eq, engagement in a TCP is even less attractive. For these farmers, NPVs were always lowest, making it unlikely that profit-oriented TCPs would target the poorest farmers. For such farmers, it is also likely that a discount rate of $12 \%$ is unrealistic. From a study of small farmers in the Philippines, Lumley (1997) concluded that discount rates as high as 40-50\% are more appropriate for small, resource-constrained farmers. Raising the discount rate to $40 \%$ reduced the NPV for 2-ha farms to negligible values between US\$0.54 and US\$6.44, under the P30\% payment scheme, and to US $\$ 28.00$ for the P0.02 scheme. At a $50 \%$ discount rate, NPVs were between US\$0.29 and US\$3.45 for the P30 \% scheme and US\$24.00 for the P0.02 payment option. These findings mirror results from a recent study on carbon sequestration through agroforestry by smallholder farmers in Mexico, where the attractiveness of such activities for farmers was found to be highly sensitive to the discount rate (BalderasTorres et al. 2010).

All these NPV estimates do not include costs for managing trees over 25 years or opportunity costs of other possible land uses. They may also be based on optimistic assumptions about transaction costs, which have been identified as the potentially greatest barrier to adoption of carbon sequestering activities by smallholder farmers (Lasco et al. 2010). Sovacool (2011) reported that in projects registered under the Clean Development Mechanism, typical transaction costs are about $5 \%$ of the contract value, but for a project rewarding small farmers in Mexico for implementing agroforestry practices, Balderas-Torres et al. (2010) reported transaction costs of between $17 \%$ and $24 \%$ of the project value. Their study estimated that for farms averaging 13 ha, carbon prices between US\$5.3 and 11.5 per $\mathrm{Mg} \mathrm{CO}$-eq (US\$19.3-42.1 per $\mathrm{Mg} \mathrm{C}$ ) were required in order to break even, in projects involving up to 1,538 farmers. At comparable carbon prices, our hypothetical projects in the Sahel required about 20,000 farms with 6 or more ha to break even, indicating lower potential for smallholder carbon projects in the Sahel than in Mexico.

These considerations indicate that carbon sequestration in dryland areas using agroforestry practices is unattractive for smallholder farmers, if these activities are pursued solely to attract carbon payments. These findings cast doubts on the prospects of carbon payments to alleviate poverty among the poorest farmers in the Sahel, if carbon sequestration is the main focus.

Some recent studies have highlighted the potential of smallholder farmers to receive payments for other environmental services, such as biodiversity conservation, watershed 
protection or landscape beauty (Milder et al. 2010). Where such payments can be bundled with carbon payments, returns to farmers may increase (Wendland et al. 2010). Bundling of ecosystem services has been shown to have potential in areas of high biodiversity (e.g. Madagascar; Wendland et al. 2010) or where potential areas for carbon sequestration also fulfill important watershed or recreational functions (e.g. Phillippines; Villamor and Lasco 2009). In the relatively scarcely populated drylands of the Sahel, however, it seems doubtful that significant payments for non-carbon ecosystem services could be generated. Biodiversity in these systems is relatively low compared to the humid tropics, and demand for local ecosystem services, such as watershed conservation or landscape beauty is unlikely to be high enough to generate cash flows to farmers, except potentially in the periphery of cities.

From the presented data and discussion, it is clear that carbon as a commodity is not sufficiently valuable to provide incentives for farmers in the Sahel to involve in TCPs. However, the suite of benefits that trees provide can be of much greater value. For instance, growing the fertilizer tree Faidherbia albida in the Sahel can increase crop yields by between $50 \%$ and $170 \%$ (Garrity et al. 2010). Erosion control, improved microclimates and improved water and nutrient efficiency can further contribute to overall landscape health. Tree products can also help diversify the number of marketable products or improve family health (e.g. through essential vitamins in fruits). This can provide financial assets or higher food security, reducing farmer vulnerability to climatic and other exogenous shocks. Additional marketable products, soil fertility or favorable microclimatic conditions can help adapt farmers to climate variability and climate change (Haglund et al. 2011). Hence, the carbon component of projects could potentially serve as a catalyst that allows farmers to invest in climate-smart practices such as agroforestry, particularly where up-front payments can be realized (Neufeldt et al. 2011).

Farmers elsewhere have adopted agroforestry practices for a wide range of reasons, including additional income from trees, soil conservation, production of construction materials, diversity of harvest and shelter from strong winds (Magcale-Macandog et al. 2006). In Maradi, Niger, recent farmer-managed regeneration of parkland systems seems to have been motivated primarily by the prospects of improved soil fertility, and the production of fuelwood and marketable tree products, resulting in additional income (Haglund et al. 2011). Haglund et al. (2011) estimated that the deliberate protection and management of naturally growing parkland trees has raised income levels by between US\$26 and US\$46 per capita and year. These estimates are much higher than potential incomes from carbon sales estimated in the present study. Non-carbon benefits thus appear to have a greater positive effect on farm profitability than payments for sequestering carbon.

\subsection{Climate change impacts and adaptation}

Rather than benefitting from opportunities provided by climate change, farmers in the Sahel may find themselves confronted with severely deteriorating climatic conditions. Our analysis indicated that parkland systems may experience increasingly unsuitable conditions, which may lead to range contractions. Trying to raise landscape level carbon stocks against this climatic trend may prove impossible. Maranz (2009) reported that many tree taxa in this environment are already in decline and that savannah parklands are senescing due to decreasing rainfall. Gijsbers et al. (1994) reported that seedlings of key tree species are no longer able to survive during the dry season. These observations may be symptoms of decreasing suitability for parklands.

Where parkland areas can be expanded, these may help farmers adapt to the impacts of climate change. Unlike rainfed annual crops, trees can draw water from deeper soil layers 
and are thus able to produce food, fodder and fiber, even when annual crops fail. Fertilizer trees can provide much-needed resources that allow raising yield levels. Finally, trees on farms can help diversify incomes and thus buffer farmers against the economic shocks that may occur during years of unfavorable weather.

The climate trajectory for the Sahel is far from clear. With projections ranging from unchanged conditions to strongly increasing aridity, governments and farmers have no unequivocal basis for managing the transition. However, with many future scenarios indicating increasing aridity, it seems likely that inadequate efforts to adapt will make farmers increasingly vulnerable to the extremes of a rainfall distribution that is shifted towards drier conditions than prevail today. The cost of the necessary adaptation measures is likely to exceed the value of carbon that can be stored in Sahelian cropping systems. It appears that in the Sahel, the opportunities provided by climate change will be greatly outweighed by the challenges it presents.

\section{Conclusions}

Carbon stocks in Sahelian parklands are substantially higher than in croplands in this region, but deterioration of climatic conditions may reduce suitable ranges for this agroecosystem. Substantial climate risks are thus incurred in the establishment of parklands for carbon sequestration, especially if carbon sales are needed to make such efforts economically viable. Even if climatic conditions remain unchanged, economically viable Terrestrial Carbon Projects (TCPs) require large numbers of farmers and carbon prices that are higher than at present. Economics on the farmers' side made carbon sequestration seem like an economically unattractive option. Nevertheless, the recent re-establishment of thousands of hectares of parklands in Southern Niger, without any payments for carbon sequestration, indicates that non-carbon benefits may very well be a motivating factor leading to largescale establishment of parklands.

Providing benefits from TCPs to the poorest farmers will be challenging, because such farmers are the least profitable ones for investors to work with. Net Present Values for small farmers were low, especially when considering the high discount rate on future revenue that they likely apply. The unpredictability of the ecological and economic framework for carbon projects in the Sahel, with uncertainty about future climate and the survival of trees, as well as future carbon prices, make this region a high-risk area for profit-oriented investments in TCPs.

Acknowledgments We appreciate the help of Gray Tappan at the US Geological Survey, who provided USGS land use data for use in this study, even before their official release. We are also grateful to Tanja Havemann, Director of BeyondCarbon $\mathrm{GmbH}$ in Zurich for making her biocarbon business model available to us.

\section{References}

Ajayi OC, Akinnifesi FK, Sileshi G, Chakeredza S (2007) Adoption of renewable soil fertility replenishment technologies in the southern African region: lessons learnt and the way forward. Nat Resour Forum 31:306-317

Albrecht A, Kandji ST (2003) Carbon sequestration in tropical agroforestry systems. Agric Ecosyst Environ 99:15-27 
Allen RG, Pereira LS, Raes D, Smith M (1988) Crop evapotranspiration-guidelines for computing crop water requirements. FAO-Food and Agriculture Organization of the United Nations, Rome

Balderas-Torres A, Marchant R, Lovett JC, Smart JCR, Tipper R (2010) Analysis of the carbon sequestration costs of afforestation and reforestation agroforestry practices and the use of cost curves to evaluate their potential for implementation of climate change mitigation. Ecol Econ 69:469-477

Bayala J, Teklehaimanot Z, Ouedraogo SJ (2002) Millet production under pruned tree crowns in a parkland system in Burkina Faso. Agrofor Syst 54:203-214

Bayala J, Teklehaimanot Z, Ouedraogo SJ (2004) Fine root distribution of pruned trees and associated crops in a parkland system in Burkina Faso. Agrofor Syst 60:13-26

Bayala J, Balesdent J, Marol C, Zapata F, Teklehaimanot Z, Ouedraogo SJ (2006) Relative contribution of trees and crops to soil carbon content in a parkland system in Burkina Faso using variations in natural C13 abundance. Nutr Cycl Agroecosyst 76:193-201

Bellucci A, Gualdi S, Navarra A (2010) The double-ITCZ syndrome in coupled general circulation models: the role of large-scale vertical circulation regimes. J Clim 23:1127-1145

Bouvet JM, Fontaine C, Sanou H, Cardi C (2004) An analysis of the pattern of genetic variation in Vitellaria paradoxa using RAPD markers. Agrofor Syst 60:61-69

Cannell MGR, Van Noordwijk M, Ong CK (1996) The central agroforestry hypothesis: the trees must acquire resources that the crop would not otherwise acquire. Agrofor Syst 34:27-31

CARE (2011) Making carbon finance for sustainable agriculture work for poor people. CARE, Kenya

Deans JD, Munro RC (2004) Comparative water use by dryland trees in Parklands in Senegal. Agrofor Syst $60: 27-38$

Diaz D, Hamilton K, Johnson E (2011) State of the forest carbon markets 2011 — from canopy to currency. Ecosystem Marketplace, Forest Trends, Washington, D.C

Dumanski J, Desjardins RL, Tarnocai C, Monreal C, Gregorich EG, Kirkwood V, Campbell CA (1998) Possibilities for future carbon sequestration in Canadian agriculture in relation to land use changes. Clim Chang 40:81-103

Garrity DP (2004) Agroforestry and the achievement of the millennium development goals. Agrofor Syst 612:5-17

Garrity D, Akinnifesi F, Ajayi O, Weldesemayat S, Mowo J, Kalinganire A, Larwanou M, Bayala J (2010) Evergreen agriculture: a robust approach to sustainable food security in Africa. Food Secur 2:197-214

Gijsbers HJM, Kessler JJ, Knevel MK (1994) Dynamics and natural regeneration of woody species in farmed parklands in the Sahel Region (Privince of Passore, Burkina-Faso) For. Ecol Manag 64:1-2

Haglund E, Ndjeunga J, Snook L, Pasternak D (2011) Dry land tree management for improved household livelihoods: farmer managed natural regeneration in Niger. J Environ Manag 92:1696-1705

Hargreaves GL, Hargreaves GH, Riley JP (1985) Irrigation water requirements for Senegal River Basin. J Irrig Drain Eng-Asce 111:265-275

Hernandez PA, Graham CH, Master LL, Albert DL (2006) The effect of sample size and species characteristics on performance of different species distribution modeling methods. Ecography 29:773-785

Hijmans RJ, Graham CH (2006) The ability of climate envelope models to predict the effect of climate change on species distributions. Glob Chang Biol 12:2272-2281

Hijmans RJ, Cameron SE, Parra JL, Jones PG, Jarvis A (2005) Very high resolution interpolated climate surfaces for global land areas. Int J Climatol 25:1965-1978

IPCC (2000) IPCC special report on land use, land-use change and forestry. Cambridge University Press, Cambridge

IPCC (2007) Climate change 2007-synthesis report. Contributions of working groups I, II and III to the fourth assessment report of the intergovernmental panel on climate change. Intergovernmental Panel on Climate Change, Geneva, Switzerland

Jose S (2009) Agroforestry for ecosystem services and environmental benefits: an overview. Agrofor Syst 76:1-10

Kater LJM, Kante S, Budelman A (1992) Karité (Vitellaria paradoxa) and Néré (Parkia biglobosa) associated with crops in South Mali. Agrofor Syst 18:89-105

Kelly BA, Bouvet JM, Picard N (2004) Size class distribution and spatial pattern of Vitellaria paradoxa in relation to farmers' practices in Mali. Agrofor Syst 60:3-11

Kho RM, Yacouba B, Yaye M, Katkore B, Moussa A, Iktam A, Mayaki A (2001) Separating the effects of trees on crops: the case of Faidherbia albida and millet in Niger. Agrofor Syst 52:219-238

Kindt R, Kalinganire A, Larwanou M, Belem M, Dakouo JM, Bayala J, Kaire M (2008) Species accumulation within land use and tree diameter categories in Burkina Faso, Mali, Niger and Senegal. Biodivers Conserv 17:1883-1905

Kuersten E, Burschel P (1993) $\mathrm{CO}_{2}$-mitigation by agroforestry. Water Air Soil Pollut 70:533-544

Lasco RD, Evangelista RS, Pulhin FB (2010) Potential of community-based forest management to mitigate climate change in the Philippines. Small-Scale For 9:429-443 
Luedeling E, Sileshi G, Beedy T, Dietz J (2011) Carbon sequestration potential of agroforestry systems in Africa. In: Kumar BM, Nair PKR (eds) Carbon sequestration potential of agroforestry systems: opportunities and challenges. Springer Science+Business Media B.V., Dordrecht, pp. 61-83

Lumley S (1997) The environment and the ethics of discounting: an empirical analysis. Ecol Econ 20:71-82

Magcale-Macandog DB, Visco RG, Delgado MEM (2006) Agroforestry adoption, innovations and smallholder farmers' motivations in tropical uplands of Southern Philippines. J Sustain Agric 28:131-143

Maranz S (2009) Tree mortality in the African Sahel indicates an anthropogenic ecosystem displaced by climate change. J Biogeogr 36:1181-1193

Maranz S, Wiesman Z, Bisgaard J, Bianchi G (2004) Germplasm resources of Vitellaria paradoxa based on variations in fat composition across the species distribution range. Agrofor Syst 60:71-76

Milder JC, Scherr SJ, Bracer C (2010) Trends and future potential of payment for ecosystem services to alleviate rural poverty in developing countries. Ecol Soc 15:6

Montagnini F, Nair PKR (2004) Carbon sequestration: an underexploited environmental benefit of agroforestry systems. Agrofor Syst 61-2:281-295

Nair PKR (2007) Agroforestry for sustainability of lower-input land-use systems. J Crop Improv 19:25-47

Nair PKR, Kumar BM, Nair VD (2009a) Agroforestry as a strategy for carbon sequestration. J Plant Nutr Soil Sci-Z Pflanzenernahr Bodenkd 172:10-23

Nair PKR, Nair VD, Kumar BM, Haile SG (2009b) Soil carbon sequestration in tropical agroforestry systems: a feasibility appraisal. Environ Sci Pol 12:1099-1111

Neufeldt H, Kristjanson P, Thorlakson T, Gassner A, Norton-Griffiths M, Place F, Langford K (2011) Making climate-smart agriculture work for the poor. ICRAF Policy Brief 12. World Agroforestry Centre, Nairobi

Odebiyi JA, Bada SO, Omoloye AA, Awodoyin RO, Oni PI (2004) Vertebrate and insect pests and hemiparasitic plants of Parkia biglobosa and Vitellaria paradoxa in Nigeria. Agrofor Syst 60:51-59

Paustian K, Cole CV, Sauerbeck D, Sampson N (1998) CO2 mitigation by agriculture: an overview. Clim Chang 40:135-162

Pearson RG, Raxworthy CJ, Nakamura M, Townsend Peterson A (2007) Predicting species distributions from small numbers of occurrence records: a test case using cryptic geckos in Madagascar. J Biogeogr 34:102-117

Phillips SJ, Dudík M (2008) Modeling of species distributions with Maxent: new extensions and a comprehensive evaluation. Ecography 31:161-175

Phillips SJ, Anderson RP, Schapire RE (2006) Maximum entropy modeling of species geographic distributions. Ecol Model 190:231-259

Reij C, Tappan G, Belemvire A (2005) Changing land management practices and vegetation on the Central Plateau of Burkina Faso (1968-2002). J Arid Environ 63:642-659

Reij C, Tappan GG, Smale M (2009) Agroenvironmental transformation in the Sahel—another kind of "Green Revolution". IFPRI Discussion Paper No. 914:1-52

Sanchez PA (1995) Science in agroforestry. Agrofor Syst 30:5-55

Sinclair FL (1999) A general classification of agroforestry practice. Agrofor Syst 46:161-180

Smith P, Martino D, Cai Z, Gwary D, Janzen H, Kumar P, McCarl B, Ogle S, O'Mara F, Rice C, Scholes B, Sirotenko O, Howden M, McAllister T, Pan G, Romanenkov V, Schneider U, Towprayoon S, Wattenbach M, Smith J (2008) Greenhouse gas mitigation in agriculture. Philos Trans R Soc B-Biol Sci 363:789-813

Sovacool BK (2011) Four problems with global carbon markets: a critical review. Energy Environ 22:681694

Stéphenne N, Lambin EF (2001) A dynamic simulation model of land-use changes in Sudano-sahelian countries of Africa (SALU). Agric Ecosyst Environ 85:145-161

Swallow BM, Kallesoe MF, Iftikhar UA, van Noordwijk M, Bracer C, Scherr SJ, Raju KV, Poats SV, Duraiappah AK, Ochieng BO, Mallee H, Rumley R (2009) Compensation and rewards for environmental services in the developing world: framing pan-tropical analysis and comparison. Ecol Soc 14(2): 26. http://www.ecologyandsociety.org/vol14/iss2/art26/

Takimoto A (2007) Carbon sequestration potential of agroforestry systems in the West African Sahel: an assessment of biological and socioeconomic feasibility. University of Florida, Gainesville

Takimoto A, Nair PKR, Nair VD (2008) Carbon stock and sequestration potential of traditional and improved agroforestry systems in the West African Sahel. Agric Ecosyst Environ 125:159-166

Thomson AM, Calvin KV, Chini LP, Hurtt G, Edmonds JA, Bond-Lamberty B, Frolking S, Wise MA, Janetos AC (2010) Climate mitigation and the future of tropical landscapes. Proc Natl Acad Sci U S A 107:19633-19638

Tilander Y, Ouedraogo G, Yougma F (1995) Impact of tree coppicing on tree-crop competition in parkland and alley farming systems in semiarid Burkina Faso. Agrofor Syst 30:363-378

Timmer LA, Kessler JJ, Slingerland M (1996) Pruning of nere trees (Parkia biglobosa (Jacq) Benth) on the farmlands of Burkina Faso, West Africa. Agrofor Syst 33:87-98 
Traore K, Ganry F, Oliver R, Gigou J (2004) Litter production and soil fertility in a Vitellaria paradoxa parkland in a catena in southern Mali. Arid Land Res Manag 18:359-368

Tschakert P (2004) Carbon for farmers: assessing the potential for soil carbon sequestration in the old peanut basin of Senegal. Clim Chang 67:273-290

US Geological Survey (2007) The West Africa land use and land cover trends project. USGS EROS Center, Sioux Falls

Van Noordwijk M, Lusiana B (1998) WaNulCAS, a model of water, nutrient and light capture in agroforestry systems. Agrofor Syst 43:217-242

van Noordwijk M, Ong CK (1999) Can the ecosystem mimic hypotheses be applied to farms in African savannahs? Agrofor Syst 45:131-158

VCS (2011) Agriculture, Forestry and Other Land Use (AFOLU) requirements v. 3.0. Verified Carbon Standard Association

Villamor GB, Lasco RD (2009) Rewarding upland people for forest conservation: experience and lessons learned from case studies in the Philippines. J Sustain For 28:304-321

Wendland KJ, Honzák M, Portela R, Vitale B, Rubinoff S, Randrianarisoa J (2010) Targeting and implementing payments for ecosystem services: opportunities for bundling biodiversity conservation with carbon and water services in Madagascar. Ecol Econ 69:2093-2107

Woomer PL, Tieszen LL, Tappan G, Touré A, Sall M (2004) Land use change and terrestrial carbon stocks in Senegal. J Arid Environ 59:625-642

Wunder S (2008) Payments for environmental services and the poor: concepts and preliminary evidence. Environ Dev Econ 13:279-297 